\title{
Labor of Love $\infty$
}




\section{FAMilies in Focus}

\section{Series Editors}

Naomi R. Gerstel, University of Massachusetts, Amherst

Karen V. Hansen, Brandeis University

Rosanna Hertz, Wellesley College

Margaret K. Nelson, Middlebury College

Katie L. Acosta, Amigas y Amantes: Sexually Nonconforming Latinas Negotiate Family

Riché J. Daniel Barnes, Raising the Race: Black Career Women Redefine Marriage, Motherhood, and Community

Ann V. Bell, Misconception: Social Class and Infertility in America

Mignon Duffy, Amy Armenia, and Clare L. Stacey, eds., Caring on the Clock: The Complexities and Contradictions of Paid Care Work

Anita Ilta Garey and Karen V. Hansen, eds., At the Heart of Work and Family: Engaging the Ideas of Arlie Hochschild

Heather Jacobson, Labor of Love: Gestational Surrogacy and the Work of Making Babies

Katrina Kimport, Queering Marriage: Challenging Family Formation in the United States

Mary Ann Mason, Nicholas H. Wolfinger, and Marc Goulden, Do Babies Matter? Gender and Family in the Ivory Tower

Jamie L. Mullaney and Janet Hinson Shope, Paid to Party: Working Time and Emotion in Direct Home Sales

Markella B. Rutherford, Adult Supervision Required: Private Freedom and Public Constraints for Parents and Children

Barbara Wells, Daughters and Granddaughters of Farmworkers: Emerging from the Long Shadow of Farm Labor 


\section{Labor of Love

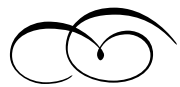

Gestational Surrogacy and the Work of Making Babies

HEATHER JACOBSON 


\section{Library of Congress Cataloging-in-Publication Data}

Jacobson, Heather.

Labor of love : gestational surrogacy and the work of making babies / Heather Jacobson. pages $\mathrm{cm}$. - (Families in focus)

Includes bibliographical references and index.

ISBN 978-0-8135-6951-2 (hardcover : alk. paper) - ISBN 978-0-8135-6950-5

(pbk. : alk. paper) - ISBN 978-o-8135-6952-9 (e-book (web pdf))

1. Surrogate motherhood. 2. Surrogate mothers. 3. Human reproductive technology-Social aspects. 4. Families. I. Title.

HQ759.5.J33 2016

$306.8744^{\prime} 3-\mathrm{dc} 23$

2015021891

A British Cataloging-in-Publication record for this book is available from the British Library.

Copyright $(0) 2016$ by Heather Jacobson

All rights reserved

No part of this book may be reproduced or utilized in any form or by any means, electronic or mechanical, or by any information storage and retrieval system, without written permission from the publisher. Please contact Rutgers University Press, 106 Somerset Street, New Brunswick, NJ 08901. The only exception to this prohibition is "fair use" as defined by U.S. copyright law.

Visit our website: http://rutgerspress.rutgers.edu

Manufactured in the United States of America 
For Seiichiro and Miya 
